\title{
LABOR EFFICIENT
}

\section{By Hon. Henry F. Hollis,}

Member of Committee on Education and Labor, United States Senate.

I was once the captain of a baseball team playing an important series. My side won by a narrow margin. A man who bet on the wrong team said to me, "Those fellows batted harder and fielded better than your men. How did you pull it out?" My reply was, "When we had to have a run, we got it. We depended on fighting spirit instead of percentages."

You cannot win a battle with listless soldiers, or Hessians. You cannot get maximum production with listless workmen, or outsiders. Wages, hours of labor, sanitation, and the rest of it, are important, but they are only batting and fielding averages. We must have enthusiasm and morale, tons of them. We must make the working-man believe that we are really fighting for liberty, and not for profits. Instead of treating working-men like beasts of burden, to be kindly treated and well fed, we must treat them like partners and saviors of the nation.

There really is not much we can do. We shall do well if we undo most of what we have done. To begin with we must make restitution. We must return to labor its stolen property. I do not mean profits. I mean the war itself. For this war is labor's war, and labor knows it. Give labor back its war, and do not worry about any labor stimulant.

The best of us are prone to put on full dress and talk down to labor. We feel that we are broad-minded to notice labor's existence. Labor knows this, and good-humoredly tolerates our weakness. Working-men are better informed than we on the real issues of the day. They know that they can get along without us, but we cannot get along without them. They also know that we are ignorant of this solemn fact.

Labor knows that all we need to win this war is men to fight, property and labor. We need a few super-workmen like President Wilson, Secretary Wilson, Henry Ford, Hoover and Schwab, but 
we can get along very nicely without the owners of property. If they will not loan us their property, we can take it by taxation. We can conscript soldiers and we can conscript wealth; but the spirit which makes American labor the most efficient on earth cannot be conscripted. Nor is such conscription necessary.

Working-men, including farmers, make up this nation. The rest of us cling on the edges, a paltry handful. By dividing the workers against themselves, we skillfully appropriate the balance of power.

Labor's sons make up the bulk of our army in France. Labor weeps when our soldiers suffer; it thrills when they go over the top. Instead of asking labor to help us win our war, we ought to thank God that labor lets us knit sweaters and loan money to help it win its war. Bear in mind that this is labor's war, not only to make the world a decent place to live in, but to make the working-man's home a decent place to live in.

Cut out profiteering. Stop patronizing. Put a working-man beside every capitalist and college professor on every board. Consult labor frankly and humbly. Follow labor's advice. If your services are of any, value, proffer them. Give labor a fair chance, step out of the way and watch the smoke. And save your stimulant for yourself.

\section{THE EFFICIENCY OF LABOR}

\section{By Hon. William B. Wilson, Secretary of Labor, Washington, D. C.}

It is my purpose to discuss the subject of the efficiency of labor. But before proceeding to a statement of the policies that are being pursued to attain the end desired, it may be well to examine briefly the background leading up to our entrance into the great world war, in order that we may better understand the policies that should be pursued in dealing with the great problem of labor efficiency.

Our people are a peace-loving people. If they had not been they would not have submitted to the many indignities and wrongs heaped upon them for the length of time they did. We had dreamed 